lead levels and criminality does not appear in our cases, at least for the group of prisoners studied here.

\section{References}

Berlin, A. and Smeets, J. (1974). European intercomparison programmes and harmonization of techniques with special reference to heavy metals in biological fluids. Presented at the Fourth Annual Symposium on Recent Advances in the Analytical Chemistry of Pollutants, Basle, Switzerland.

Bryce-Smith, D. (1972). Behavioural effects of lead and other heavy metal pollutants. Chemistry in Britain, 8, 240-243.

— and Waldron, H. A. (1974a). Lead, behaviour and criminality. The Ecologist, 4, 367-377.

__ and _ (1974b). Blood-lead levels, behaviour and intelligence. (Letter). Lancet, 2, 44-45.

David, O., Clark, J., and Voeller, K. (1972). Lead and hyperactivity. Lancet, 2, 900-903.

Hoschek, R. and Schittke, H. J. (1973). Vergleichsbestimmungen für Blei in Blut sowie für Blei und Cadmium in Urin. Bundesrat für Arbeitsschutz und Unfallforschung, Dortmund.

Kotok, D. (1972). Development of children with elevated blood lead levels: a controlled study. Journal of Pediatrics, 80, 57-61.

Landrigan, P. J., Whitworth, R. H., Baloh, R. W., Staehling, N. W., Barthel, W. F., and Rosenblum, B. F. (1975). Neuropsychological dysfunction in children with chronic low-level lead absorption. Lancet, 1, 708-712.
Lansdown, R. G., Shepherd, J., Clayton, B. E., Delves, H. T., Graham, P. J., and Turner, W. C. (1974). Blood-lead levels, behaviour, and intelligence. A population study. Lancet, 1, 538-541.

Lin-Fu, J. S. (1973). Vulnerability of children to lead exposure and toxicity. New England Journal of Medicine, 289, 1229-1233, 1289-1293.

Lob, M. and Desbaumes, P. (1971). Étude de la plombémie et de la plomburie chez deux groupes de détenus, les uns internés à la campagne, les autres à proximité immédiate d'une autoroute. Schweizerische Medizinische Wochenschrift, 101, 357-361.

McCabe, E. B. (1974). Blood-lead levels, behaviour and intelligence. (Letter). Lancet, 2, 896.

- (1975). Blood-lead levels, behaviour and intelligence. (Letter). Lancet, 1, 751-752.

Mitchell, D. G., Ryan, F. J., and Aldous, K. M. (1972). The precise determination of lead in whole blood by solvent extraction. Atomic absorption spectrometry. Atomic Absorption Newsletter, 11, 120-121.

Needleman, H. L., Epstein, S., Carnow, B., Scanlon, J., Parkinson, D., Samuels, S., Mazzochi, A., and David, O. (1975). Blood-lead levels, behaviour and intelligence. (Letter). Lancet, 1, 751.

Valloton, M. N., Guillemin, M., and Lob, M. (1973). Plombémie et activité de la déhydratase de l'acide $\delta$-aminolévulinique dans une population lausannoise. Schweizerische Medizinische Wochenschrift, 193, 548-550.

Received for publication 27 October 1975

Accepted for publication 23 January 1976

\title{
Release of histamine from lung tissue in vitro by dimethylhydantoin-formaldehyde resin and polyvinylpyrrolidone
}

\author{
P. J. NICHOLLS \\ Welsh School of Pharmacy, UWIST, Cardiff CF1 3NU
}

A small but definite proportion of hairdressers suffer from symptoms such as dry throat, cough, and mild breathlessness usually towards the end of a busy day(C. S. Darke, personal communication, 1965). The symp- toms appear to be associated with the use of aerosol hair lacquers. It is unlikely that concentrations of the lacquer are high enough to allow sufficient deposition of resin in the respiratory tract to produce mechanical 
obstruction leading to diffusional problems. Two possible hypotheses, however, suggest themselves to account for these effects. First, that the symptoms are due to upper respiratory tract irritation thus causing the dry cough and throat irritation. Secondly, that the symptoms are the result of a localized bronchial or bronchiolar constriction caused by a pharmacologically active agent in the inhaled lacquers acting by direct or indirect mechanisms.

As the decrease in maximum expiratory flow rate observed in human volunteers inhaling hair sprays is prevented by an antihistamine drug (Zuskin and Bouhuys, 1974), it was decided to examine the second hypothesis by investigating the histamine-releasing activity of two non-volatile film-forming agents, dimethylhydantoin-formaldehyde resin (DMHF) and polyvinylpyrrolidone (PVP, Draize et al., 1959). Although these compounds are no longer commonly employed in hair sprays, they were very popular at the time the observations on hairdressers were made by Darke.

\section{Material and methods}

The synthetic histamine reteaser, compound $48 / 80$ was purchased from Burroughs Wellcome, England. Samples of DMHF and PVP were obtained from Dr C. S. Darke (Northern General Hospital, Sheffield). For the investigation DMHF and PVP were dissolved in Tyrode's solution

Guinea-pigs of the Hartley strain and Rhesus monkeys, both of either sex, were killed by stunning and exsanguination. The lungs were removed immediately into Tyrode's solution at a temperature of $4^{\circ} \mathrm{C}$. Specimens of human lung tissue that appeared macroscopically normal were obtained from surgical lung resections in patients with bronchial carcinoma. These were also kept in Tyrode's solution at a temperature of $4^{\circ} \mathrm{C}$ until used for incubation. The animal lung was prepared for incubation without delay, but in the case of the human lung, there was an interval of approximately 2 hours between removal of the specimen and the beginning of incubation.

The histamine-releasing activity of the film-forming compounds was determined according to the procedure of Nicholls, Nicholls, and Bouhuys (1966). Chopped lung $(1 \mathrm{~g})$ was incubated for 25 minutes at $37^{\circ} \mathrm{C}$ in Tyrode's solution $(3 \mathrm{ml})$ containing these agents or compound 48/80. At the end of incubation histamine released into the medium was determined spectrophotofluorimetrically (Shore, Burkhalter, and Cohn, 1959). None of the substances included in the incubation interfered with the assay of histamine. For each lung specimen used, the histamine content was also determined by this method.

\section{Results and discussion}

The synthetic histamine releaser compound 48/80 produced a substantial release of histamine from the lung of all the species (Table). DMHF also released histamine from all three species (Table). Although only a limited number of experiments was carried out, it was evident that this effect was dose-related. PVP was a less effective histamine releaser than DMHF on lung tissue; a concentration of $5 \mathrm{mg} / \mathrm{ml}$ did not release histamine from guinea-pig lung and was effective in only one out of three specimens of human lung.

Although DMHF is a more potent histamine liberator than PVP, it was less potent than compound $48 / 80$ in all three species studied. However,

TABLE

Histamine Release from Lung Tissue IN Vitro

\begin{tabular}{|c|c|c|c|c|c|c|c|c|c|c|}
\hline \multirow{3}{*}{ Material } & \multirow{3}{*}{$\begin{array}{l}\text { Concentration* } \\
\quad(\mathrm{mg} / \mathrm{ml})\end{array}$} & \multicolumn{9}{|c|}{ Histamine release $(\%)+$} \\
\hline & & \multicolumn{2}{|c|}{ Guinea-pig } & \multicolumn{4}{|c|}{ Monkey } & \multicolumn{3}{|c|}{ Human } \\
\hline & & 1 & 2 & 1 & 2 & 3 & 4 & 1 & 2 & 3 \\
\hline DMHF§ & $\begin{array}{l}5 \\
3\end{array}$ & $2 \cdot 4$ & - & - & $\overline{4 \cdot 1}$ & $\overline{2 \cdot 7}$ & $5 \cdot 4$ & $\begin{array}{l}7 \cdot 9 \\
-\end{array}$ & $\stackrel{8 \cdot 8}{-}$ & $\overline{8 \cdot 7}$ \\
\hline & 1 & - & 0.9 & $2 \cdot 24$ & - & - & 0.9 & $1 \cdot 8$ & $2 \cdot 9$ & $4 \cdot 1$ \\
\hline PVP§ & 5 & 0 & 0 & - & $1 \cdot 2$ & - & 1.5 & 0 & 0 & $2 \cdot 0$ \\
\hline & 1 & - & - & 0.56 & - & $0 \cdot 11$ & - & 一 & - & - \\
\hline Compound 48/80 & 1 & $4 \cdot 2$ & $7 \cdot 9$ & $4 \cdot 5$ & $4 \cdot 3$ & $2 \cdot 5$ & $7 \cdot 6$ & $6 \cdot 0$ & $9 \cdot 2$ & $14 \cdot 0$ \\
\hline $\begin{array}{l}\text { Histamine con- } \\
\text { tent }(\mu \mathrm{g} / \mathrm{g} \text { of lung })\end{array}$ & & $30 \cdot 0$ & $17 \cdot 0$ & $51 \cdot 0$ & $62 \cdot 1$ & $39 \cdot 5$ & $24 \cdot 5$ & $17 \cdot 0$ & $29 \cdot 4$ & $23 \cdot 1$ \\
\hline
\end{tabular}

For each species, chopped lung $(1 \mathrm{~g})$ was incubated in a final volume of $3 \mathrm{ml}$ Tyrode's solution for $25 \mathrm{~min}$ at $37^{\circ} \mathrm{C}$. Histamine liberated into the incubation medium was assayed fluorimetrically. Blank spaces indicate that no determination was made *Final concentration in incubating medium

tHistamine released expressed as percentage of the total histamine in the lung sample $(1 \mathrm{~g})$; results are the means of duplicate determinations from one lung sample in each experiment

$\S D M H F=$ dimethylhydantoin-formaldehyde resin; PVP = polyvinylpyrrolidone 
these findings demonstrate the potential of these agents, and thus of hair lacquer containing them, to produce changes in lung function by an indirectly acting mechanism. It is interesting to note that the activity of these hair spray constituents is apparently not species-dependent in contrast to the histaminereleasing activity of cotton dust (Evans and Nicholls, 1974). Inhalation of histamine releasers by human subjects has been shown to produce changes in pulmonary function related, in part, to bronchoconstriction. Thus inhalation of cotton dust causes a rise of airway resistance and a decrease in the forced expiratory volume during $1 \mathrm{~s}$ (Bouhuys and Nicholls, 1966) and inhalation of $48 / 80$ by asthmatic subjects gives rise to mild broncho-constriction (Vukobratović, 1966). It is possible, therefore, that the histamine-releasing activity of DMHF and PVP is sufficient to cause changes in pulmonary function when these compounds are inhaled as part of hair lacquer aerosols. The release of histamine could account for the slow disappearance of the airway constrictor effect of inhaled hair sprays in man (Zuskin and Bouhuys, 1974) and DMHF would appear to be the more likely to precipitate such functional changes. Further studies are needed to establish the importance of the histamine-releasing activity of these hair spray constituents and if the components of the currently widely used sprays share this activity.

The author wishes to thank the Medical Research Council for a grant and Dr C. S. Darke for supplying samples of DMHF and PVP and for his interest in this work.

\section{Reierences}

Bouhuys, A. and Nicholls, P. J. (1966). The effect of cotton dust on respiratory mechanics in man and in guinea pigs. In Inhaled Particles and Vapours, II: Proceedings of an International Symposium, Cambridge, 1965 , edited by C. N. Davies, pp. 75-85. Pergamon, Oxford.

Draize, J. H., Nelson, A. A., Newburger, S. H., and Kelly, E. A. (1959). Inhalation toxicity studies of six types of aerosol hair spray. Proceedings of the Scientific Section of the Toilet Goods Association, 31, 28-32.

Evans, E. and Nicholls, P. J. (1974). Comparative study of histamine release by cotton dust from the lung of several species. Comparative and General Pharmacology, 5, 87-90.

Nicholls, P. J., Nicholls, G. R., and Bouhuys, A. (1966). Histamine release by compound $48 / 80$ and textile dusts from lung tissue in vitro. In Inhaled Particles and Vapours, II: Proceedings of an International Symposium Cambridge, 1965, edited by C. N. Davies, pp. 67-74. Pergamon, Oxford.

Shore, P. A., Burkhalter, A., and Cohn, V. H. (1959). A method for the fluorimetric assay of histamine in tissues. Journal of Pharmacology and Experimental Therapeutics, 127, 182-186.

Vukobratović, S. (1966). Comparison entre les rhinites allergiques et l'asthme bronchique évalué par l'action des substances histamino-libératrices sur les bronches et sur la muqueuse nasale. Acta Allergologica, 21, 310-318.

Zuskin, E. and Bouhuys, A. (1974). Acute airway responses to hair-spray preparations. New England Journal of Medicine, 290, 660-663.

Received for publication 21 April 1975

Accepted for publication $Y$ January 1976 